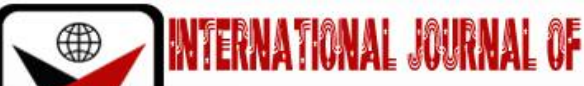

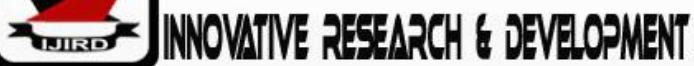

ISSN 2278 - 0211 (Online)

\section{Evaluation of Physico-chemical Properties and Heavy Metal Concentration on Three Different Rivers in Niger Delta Area, Nigeria}

\author{
Opene G. A. \\ Student, Department of Soil Science, Federal University of Technology, Imo State, Nigeria
}

\begin{abstract}
:
Status of physicochemical properties, selected micronutrients ( $\mathrm{Cu}, \mathrm{Fe}, \mathrm{Zn}, \mathrm{B}, \mathrm{Mn}$ and $\mathrm{Co}$ ) and heavy metals (Cd, $\mathrm{Pb}$, Ni, $\mathrm{Cr}$, As, and $\mathrm{Hg}$ ) were examined in the three (3) rivers (i.e. Niger, Orashi and Sombreiro/Nkissa) in Ogba/Egbema/Ndoni, a commercial oil producing area in Niger Delta, Nigeria. Results of physicochemical shows that dissolved oxygen (DO), biochemical oxygen demand (BOD) salinity, total dissolved solid (TDS), total suspended solid (TSS), turbidity, ammonium $\left(\mathrm{NH}_{4}\right), \mathrm{PO}_{4}^{2-a n d} \mathrm{Cl}$ were all within the provisional guideline values for surface or drinking water. Whereas; temperature, $\mathrm{pH}$, electrical conductivity (EC), total hydrocarbon (THC), except $\mathrm{SO}^{2}$ and $\mathrm{NO}^{-3}$ were below the international quality criteria for public surface or drinking water. Mean concentration of micronutrients in water were: $\mathrm{Cu}(0.34,0.42 \& 0.51) \mathrm{mgl}^{-1} ; \mathrm{Fe}(0.43,0.46 \& 0.49) \mathrm{mgl}^{-1} ; \mathrm{Zn}(0.21,0.35 \& 0.52) \mathrm{mgl}^{-1} ; B(2.15,3.06 \& 3.47)$ $\mathrm{mgl}^{-1} ; \mathrm{Mn}(0.098,0.135 \& 0.174) \mathrm{mgl}^{-1}$ and $\mathrm{Co}(1.05,0.12 \& 0.17) \mathrm{mgl}$. Except Cu, Fe, and $\mathrm{Zn}$; micronutrients contents of the water were above the international quality criteria for public surface water for drinking type. The result indicates that the values of $\mathrm{Cu}, \mathrm{Zn}, \mathrm{B}$ and $\mathrm{Co}$ were significantly different. Heavy metals content in water were: $\mathrm{Cd}(0.02,0.01$ \&0.04) $\mathrm{mgl}^{-1} ; \mathrm{Pb}(0.12,0.01 \& 0.06) \mathrm{mgl}^{-1} ; \mathrm{Cr}(0.38,0.39$ \& 0.57$) \mathrm{mgl}^{-1} ; \mathrm{As}(0.11,0.01 \& 0.12) \mathrm{mgl}^{-1} ; \mathrm{Ni}(0.47,0.57$ \& $0.73) \mathrm{mgl}^{-1}$ and $\mathrm{Hg}(0.065,0.097 \& 0.091) \mathrm{mgl}^{-1}$. The result revealed that heavy metals concentration in rivers Niger, Orashi and Nkissa were exceedingly above the WHO and FEPA recommended permissible level. The values obtained were observed to be significantly different at LSD (0.05)
\end{abstract}

Keywords: Pollution, water, heavy metals, properties, evaluation

\section{Introduction}

Presently rivers Niger, Orashi, and Sombreiro/Nkissa environments receives local or more widely a variety of stress resulting from human activities and natural cycle of erosion deposition due to flood. Both natural and anthropogenic sources have contributed in producing heavy metals into the aquatic environment (Agbozu et al 2007). This has inevitably increased the levels of metal ions in the rivers to an excessive concentration thereby affecting the river biota and possess risk to consumer of sea/ river food.

Ogba/Egbema/Ndoni local government area (ONELGA) play host to multi oil wells, active oil fields with a labyrinth of pipeline carrying oil or gas to flow stations of oil and gas wells thereby causing heavy discharge of industrial waste product, gas flaring, pipelines leakages, bunkering among others through oil and gas exploitation. Horsefall and Spiff (2001) reported mobile clean of 40,000 barrels both in marine and fresh water ecosystem as affected by crude oil spill of $30 \mathrm{~cm}$ diameter pipelines mobile platform raptured at Eket 1998. Nowadays, oil spill has become almost daily/weekly event owing to illegal bunkering, pipeline vandalism and expired pipelines still in use by the multinational companies operating in the Niger delta area. UNEP (2011) reputed an average of 273 oil spills with a volume of 115,000 barrels occurred annually in the Niger delta. However, ONELGA has a network of fresh water rivers -Niger, Orashi and Nkissa meandering strongly through creeks and streams into the swamps and canals were affected by incessant crude oil pollution from abundant pipelines, sabotage, poor maintenance of oil facilities (Legbrasi, 2007).

In November, 2015; a major oil tank in Ebocha Gas Plant exploded and content discharged into the Orashi and Nkissa rivers through the creek within the location. On the 19th October, 2019 a major pipeline that conveys crude oil to Ebocha pipeline exploded and emptied its contents into the Orashi R. and Niger R. via Nkissa creek and high-level flood in the area facilitated its flow to other conflux. Illegal bunkering activities is common within the creeks and most times the boats carrying these products are blown down by security agent or fire out-break thereby increasing the concentration of crude oil related contents in the water environment. Above all, the activities of Starling Global International- a new oil drilling company that loads and trans-sload oil into mini-ship in river Niger at Ndoni area. Over ten mini vessels are loaded or trans loaded at Ndoni jetty and some of these carriage vessels have leakages and deposits maximum quantity of the crude to the river. which makes the water environment to have constantly some percentage of crude oil deposit containing heavy metals. 
However, rivers Niger, Orashi and Nkissa with surrounding creeks are strong livelihood and supporting base for the inhabitants and their neighborhoods. They are source of drinking and bathing water for fisher folks of Ndoni, Egbema and Ogba, who are in close contact with the water. Fishing, transportation, recreation, sand mining and other commercial activities in the area. Heavy metals with high toxicity and potential for bioaccumulation are providing pollutants in area in view. The availability of these metals in water in excess threshold values was earlier reported to affect biodiversity. These metals tend to accumulate in sediments which may act as short- or long-term sink in the aquatic systems and source for further contamination. River flooding from time to time results to nature/ cycle of erosion and deposition of materials such as oil contaminants are carried by flood into the soils. The presence of metal pollutants in fresh water has been found to disturb the delicate balance of the aquatic ecosystem, thus manifesting as sediments tends to concentrate some metals in their body tissues (Aiyesanmi, 2006). The pollution water resources and biota by heavy metals is of major concern especially in many industrialized countries because of their toxicity, persistence and bio accumulative nature (Ikem et al, 2003) This necessitate the need to evaluate the effect of heavy metals from pollution on the physicochemical properties of the three (3) different rivers in Niger Delta area. The knowledge about the changing concentration and distribution of heavy metals in the water body will help to provide evidence of the health quality of the wetland system which is needed for conceiving good environmental management programs for the Niger delta area.

\section{Material and Method}

\subsection{Description of the Study Area}

The study was conducted at three different rivers in Ogba/Egbema/Ndoni Local Government Area (ONELGA) of Rivers State, Nigeria located between latitudes $05^{0} 20^{1} \mathrm{~N}$ to $05^{0} 30^{1} \mathrm{~N}$ and longitude $06^{0} 3^{1} \mathrm{E}$ to $06^{0} 42^{1} \mathrm{E}$. $0 \mathrm{NELGA}^{2}$ is in the extreme north western fringe of River State and lies in the humid tropical climate controlled by the southwest moisture laden and northwestern dry cold winds resulting to rainy and dry/harmathan seasons respectively. The annual rainfall ranges from $2540 \mathrm{~mm}$ to $4520 \mathrm{~mm}$ with June, July and September being wettest months every month. Relative humidity is very high especially during rainy season. Mean minimum and maximum annual temperature is between 24-26C and 3032C.Niger river adjourns the Ndoni communities with its tributaries discharging into Orashi river in Okwuzi in Egbema, Omoku and Idu in Ogba; whereas, Sombreiro (Nkissa) river adjourns Aggah in Egbema, Igburu and Egi communities in Ogba. Both rivers, Niger, Orashi and Sombreiro (Nkissa) are characterized with active current and periodic/ annual flooding to the extent that the banks overflows causing soil inundation and surface soil flooding between $0.2 \mathrm{~cm}$ to $12 \mathrm{~m}$ height from the surface soil for about three (3) weeks to four (4) months or more. (i.e. between July to October) follows the area by receding equally experiences heavy rainfall from April to October which is occasioned by periodic rainfall between November to March is common. The area has mangrove swamp vegetation in the south while rainforest in the northern fringes. Main socio-economic activities are hunting, fishing, lumbering, small scale arable crop production in addition to commercial exploitation of crude oil.

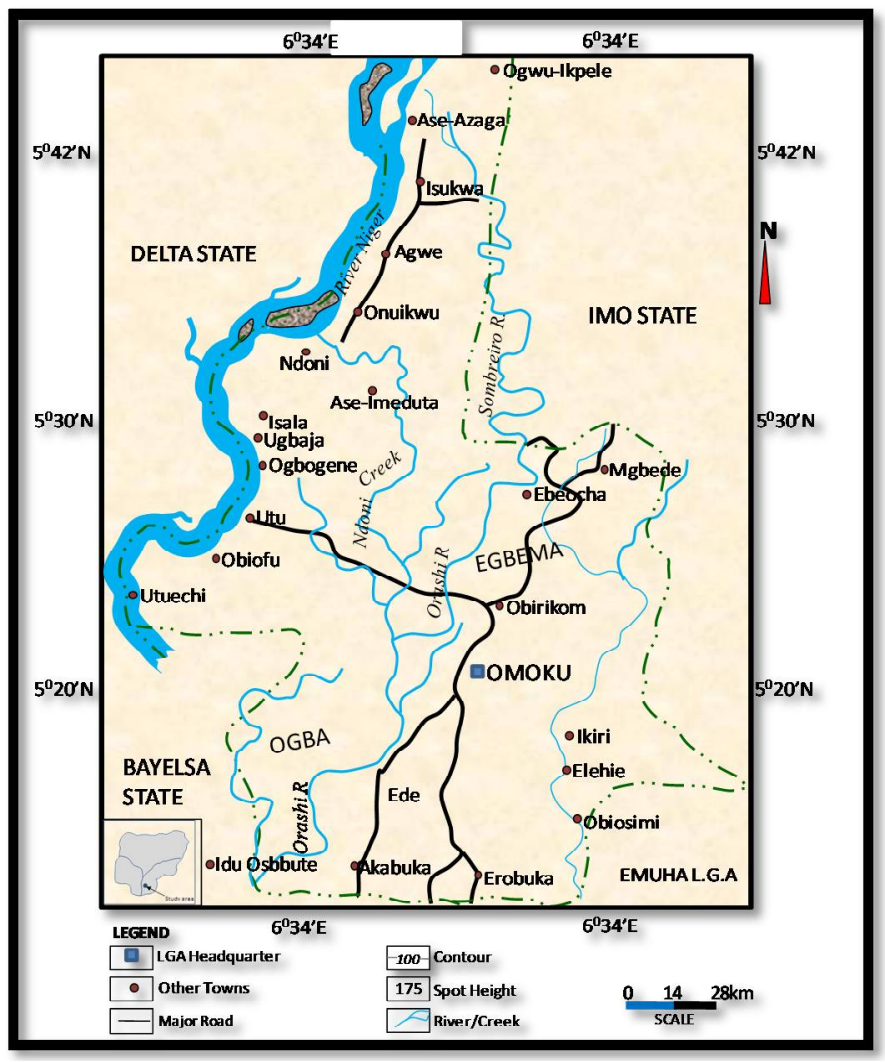

Figure 1 


\subsubsection{Field Study}

The sample station was georeferenced through global positioning system (GPS). These were upstream, downstream and mid-stream from the three (3) rivers under study in the area. Location 1: Sombreiro /Nkissa river (lat:5030' $\mathrm{N}$ and long:6 $6^{\circ} 62^{\prime} \mathrm{E}$ ); Location 2: Orashi river (lat:05028' $\mathrm{N}$ and long: $06^{0} 41^{\prime} \mathrm{E}$ ) and Location 3: Niger river (lat.05 ${ }^{\circ} 32^{\prime} \mathrm{N}$ and long:06 ${ }^{\circ} 35^{\prime} \mathrm{E}$ ) and in all meander belt of tropical rain forest. Agricultural laws and home steads are predominant and close to the locations.

Duplicated water samples were sampled using plastic bottles at the depth of $2-30 \mathrm{~cm}$ from 3 randomly selected nodes and the sub samples were homogenized to form a representative sample. For BOD, water sample were collected into dark bottles for incubation. The labelled composite sample were transferred to the laboratory stored at $5^{\circ} \mathrm{C}$ prior to further analysis.

\subsection{Laboratory Analysis}

Physicochemical properties of water with respect to DO, BO, salinity, TDS, TSS, Turbidity, $\mathrm{NH}_{4}, \mathrm{PO}_{4}^{2}, \mathrm{Cl}, \mathrm{pH}, \mathrm{NO}^{3}$, $\mathrm{SO}_{4}^{2-}$, THC, EC and temperature were determined following the standard methods (ALPHA 1998). Micro nutrients contents and heavy metal concentrations in the water samples were determined using ICP-MS (modelX7, Thermo Electron, Winsford-Cheslive, Uk). By this; $2 \mathrm{ml}$ concentrated (90\%) nitric acid (sigma-Aldrich) was added to $0.2 \mathrm{ml}$ water and the volume was made up to $10 \mathrm{ml}$ with deionized water (X5 dilution).

\subsection{Statistical Analysis}

Least Significant Difference (LSD) was adopted for analysis of data and this was performed to compare the means as the statistical significance was considered at LSD (0.05).

\section{Results and Discussion}

\subsection{Physicochemical Properties of the Rivers}

Data on physicochemical properties of the rivers: Niger, Orashi and Sombreiro/Nkissa were presented in (Table 1). Nsirimah, et al (2003) stated that water qualities determine when the physicochemical properties exist outside the permissible limits. The permissible limits of water status by FEPA (2001 \& 2010), WHO (1993) and USEPA (1989) were adapted and used to compare with the result from the study area. Dissolve Oxygen (DO) ranged from $6.57 \mathrm{mgl}^{-1}$ to 7.64 $\mathrm{mgl}^{-1}$ and values recorded were below the recommended permissible range of 8-10 $\mathrm{mgl}^{-1}$ by FEPA (2001) and WHO (1993). BOD was below FEPA (2001) maximum limit of $750 \mathrm{mgl}^{-1}$, although higher than WHO recommended maximum limit of 10 $\mathrm{mg} \mathrm{l}^{-1}$ except river Orashi with $8.88 \mathrm{mgl}^{-1}$. The least value of TDS was $2800 \mathrm{mgl}^{-1}$, this exceeds the permissible limit of 200$225 \mathrm{mgl}^{-1}$ by FEPA 2010, however lower than $500 \mathrm{mgl}^{-1}$ allowable value established by WHO (1993) and USEPA (1989). TSS value in the river were greater than $10 \mathrm{mgl}^{-1}$ (normal) in Sombreiro and Niger rivers while Orashi river value was below the recommended value. Turbidity of the rivers water were generally above the threshold value of $1.0 \mathrm{mg} / \mathrm{l}$ recommended by WHO (2001) and FEPA (2010) for aquatic lives. Ammonium $\left(\mathrm{NH}_{4}\right)$ content in water was within the allowable limit of $0.2 \mathrm{mgl}^{-1}$ in Sombrero and Orashi rivers but high in Niger. Phosphate $\left(\mathrm{PO}_{4}^{-2}\right)$ values were ranged between $0.222 \mathrm{mgl}^{-1}$ to $0.84 \mathrm{mgl}^{-1}$, this result was observed to be lower than the recommended permissible limits. Likewise, is the chloride ( $\left.\mathrm{Cl}^{-}\right)$ content of the river water. The $\mathrm{pH}$ values ranged from 6.04 to 7.94 , thus values obtained were normal when compared with both FEPA (2010) and WHO (1993) allowable value of 6-9 and 6.5-8.5 respectively. Sulphate $\left(\mathrm{SO}_{4}{ }^{2-}\right)$ content of the water and Electrical Conductivity surpassed the approved allowable /permissible limits of $500 \mathrm{mgl}^{-1}$ and $200 \mathrm{mgl}^{-1}$ respectively by FEPA(2010).Temperature of the water were slightly low in Sombreiro and Niger rivers but normal in Orashi; hence FEPA(2010) and USEPA (1989) established permissible limit for surface water temperature as $27^{\circ} \mathrm{C}$. THC content in water studied were slightly above USEPA (1989) permissible limit of $10 \mathrm{mgl}^{-1}$ in rivers Sombreiro and Niger but very low in river Orashi. The LSD (0.05) indicates that both DO, BOD and Salinity values were significantly different, TDS values was none significant in R. Niger but significant different in R. Sombreiro and R. Orashi. $\mathrm{NH}_{4}$ and $\mathrm{PO}_{4}{ }^{2-}$ values were not significant among the rivers whereas, $\mathrm{pH}$, THC, EC Temperature, contents of the water studied were all significantly different.

\subsection{Distribution of Micronutrients in the Water}

Data on selected micronutrients such as copper (Cu), iron (Fe), Zinc (Zn), Boron (B), Manganese (Mn) and Cobalt (Co) were comparatively analyzed with the allowable limit established by FEPA (2001 \& 2010) includes: $<1 \mathrm{mgl}^{-1} ; 20 \mathrm{mgl}^{-}$ ${ }^{1} ;<1 \mathrm{mgl}^{-1} ; 5 \mathrm{mgl}^{-1} ; 0.5 \mathrm{mg}^{-1}$ and $1.0 \mathrm{mgl}^{-1}$ respectively. Least value of $\mathrm{Cu}(0.340 \mathrm{mg} / \mathrm{l})$ was recorded in Sombreiro R. and the highest value $(0.505 \mathrm{mg} / \mathrm{l})$ was found in Niger river. Fe values ranged from $0.433 \mathrm{mg} / \mathrm{l}$ (Sombreiro R.) to $0.488 \mathrm{mg} / \mathrm{l}$ (Niger R.). The maximum value of $\mathrm{Zn}(0.518 \mathrm{mgl})$ was found in Niger River why the least value $\left(0.212 \mathrm{mgl}^{-1}\right)$ was recorded in Sombrero river. In the same manner, B concentration ranged from $2.154 \mathrm{mgl}^{-1}$ to $3.471 \mathrm{mgl}^{-1}$ with least value recorded in Sombreiro river. Mn in the rivers were between $0.098 \mathrm{mgl}^{-1}$ to $0.174 \mathrm{mgl}^{-1}$; Co concentration in the water were observed to range from $1.053 \mathrm{mgl}^{-1}$ to $2.453 \mathrm{mgl}^{-1}$.

The result although varies but it was observed that Sombreiro R. record the least values and the highest values of parameters studied were observed in Niger river thus, the availability of micro nutrient in the rivers was in this order: Niger river > Orashi river > Sombreiro river. $\mathrm{Cu}, \mathrm{Fe}$ and $\mathrm{Zn}$ were observed to be lower than the value established by USEPA (1989); FEPA (2001 \& 2010) and WHO (2011) whereas B, Mn and Co values indicates possibility of toxic effects if consumed and problem to aquatic organisms since they were recorded higher than international quality criteria for public 
surface water or drinking water. The micronutrients content of the water was all highly significantly different at LSD (0.05).

\subsection{Distribution of Heavy Metals in Water}

Selected heavy metals such as cadmium (Cd); lead (Pb); nickel (Ni); chromium (Cr); arsenic (As) and mercury $(\mathrm{Hg})$ concentrations in surface water were studied and the result shows variability between the three (3) rivers studied. However, a comparative analysis of the values obtained was made with FEPA (2010) and WHO (2011) established

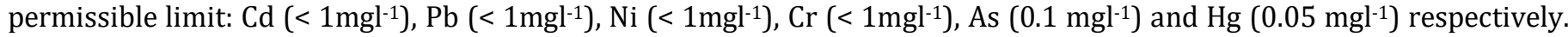
$\mathrm{Cd}$ content ranged from $0.008-0.044 \mathrm{mgl}^{-1}$ with the least value recorded in Orashi river. The concentration of $\mathrm{Pb}$ were between (0.011-0.116) $\mathrm{mgl}^{-1}$ with the maximum value found in river Sombreiro. The lowest value of Ni was obtained in the river Sombreiro $\left(0.468 \mathrm{mgl}^{-1}\right)$ and the highest value was obtained in river Niger $\left(0.727 \mathrm{mgl}^{-1}\right)$. Cr concentration ranged from $0.376-0.566 \mathrm{mgl}^{-1}$ with the least value recorded in river Sombreiro. The concentration of As in the water ranged from 0.009 to $0.118 \mathrm{mgl}^{-1}$ with the highest value obtained in river Niger. Hg content ranged from $0.065 \mathrm{mgl}^{-1}$ (Sombreiro river) to $0.091 \mathrm{mgl}^{-1}$ (river Niger). Again, the result shows that river Niger constantly recorded highest value of heavy metals. However, the heavy metals concentration in the rivers all exceeded the established permissible value by WHO (2011) and FEPA (2003) indicating possibility of toxic effects to aquatic organisms. Just like the values of micronutrients content of the water, heavy metals concentration in the water were also highly significantly different.

\section{Conclusion}

The result of this finding has revealed that both micronutrients and heavy metals concentrations in the three different rivers within the Niger Delta area were exceedingly above the international permissible safe level for human consumption and aquatic lives by World Health Organisation, Food and Agricultural Organisation and Federal Environmental Protection Authority. It is therefore imperative as a measure to boost biomonitoring of the aquatic ecosystem; activities of the multinational oil companies operating in the area and other incredible economic activities should be highly checked as a step to reduce the rate of pollution in the area as these heavy metals are biomagnified in the tissues of human beings through food chain.

\section{References}

i. APHA (1998). Standard methods for the examination of water and waste water. 20th ed. Washington: American Public Health Association

ii. Agbozu, I. E; Ekweozor, I. K. E and Opene K. (2007). Survey of heavy metals is the catfish synodontus clarias. Int'l Jam of Bavorm. Sci. Tecj 4" $93=97$

iii. Hortsfall, M and Spitt, A. (2011). Principle of Environmental pollution (with physical, chemical and biological emphasis): $1^{\text {st }}$ ed Published and printed by Metro Prints Ltd. Port Harcourt, Nigeria.

iv. FEPA. (2003). Guidelines and standard for environmental control in Nig. Nigeria Federal Environmental Agency

v. Isirimah, N.O; Dickson, A. A and Igwe C. (2003) Introductory soil chemistry and biology for agriculture and biotechnology. Osia Int'l publisher, Port Harcourt.

vi. Legborsi, S, P (2007), The adverse impacts of oil pollution on the environment and well-being of local indigenous community. The experience of the Ogoni people of Nigeria. Khabarovsk: UNDESA Khabarovsk.

vii. UNEP (2011). Environmental Assessment of Ogoni land, Nairobi, United Nations Environment Programme.

viii. WHO (2011), Guidelines for Drinking Water $4^{\text {th }}$ ed. Geneva: World Health Organization Press.

\begin{tabular}{|c|c|c|c|c|c|c|c|c|c|c|c|c|c|c|c|}
\hline Sample & DO & BOD & Salinity & TDS & TSS & Turbidity & $\mathrm{NH}_{4}$ & $\mathrm{PO}_{4}{ }^{2}$ & Cl- & pH & $\mathrm{NO}^{3}$ & $\mathrm{SO}_{4}{ }^{2-}$ & THc & EC & Temp \\
\hline 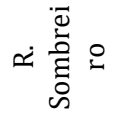 & นึำ & $\begin{array}{l}\stackrel{\infty}{N} \\
\stackrel{\sim}{\sim}\end{array}$ & $\begin{array}{l}\infty \\
\stackrel{m}{\sim}\end{array}$ & $\begin{array}{l}0 \\
\stackrel{2}{\circ} \\
6 \\
-1\end{array}$ & $\begin{array}{l}\stackrel{\sim}{\sim} \\
\stackrel{\sim}{\sim}\end{array}$ & ڤ̊ & $\begin{array}{l}\tilde{O} \\
\text { O }\end{array}$ & $\begin{array}{l}\mathbb{H}_{0} \\
0 \\
0\end{array}$ & 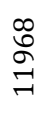 & $\frac{\sigma}{\Delta}$ & 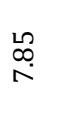 & ๙ু & $\begin{array}{l}\sigma \\
0 \\
-1\end{array}$ & $\begin{array}{l}0 \\
\stackrel{\infty}{N} \\
\stackrel{m}{m}\end{array}$ & $\hat{\stackrel{s}{s}}$ \\
\hline 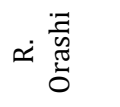 & 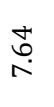 & $\begin{array}{c}\infty \\
\infty \\
\infty \\
\infty\end{array}$ & $\begin{array}{l}\infty \\
\stackrel{0}{0} \\
\sigma\end{array}$ & $\begin{array}{l}\infty \\
\stackrel{\circ}{\circ} \\
\infty\end{array}$ & $\stackrel{\text { mे }}{\text { in }}$ & $\begin{array}{l}\infty \\
\infty \\
+\end{array}$ & $\begin{array}{l}\tilde{O} \\
0 \\
0\end{array}$ & 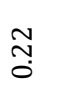 & $\begin{array}{l}\text { Na } \\
\infty \\
\infty \\
\sim \\
\sim\end{array}$ & $\stackrel{r}{~}$ & $\begin{array}{l}\text { ڤ̊ } \\
\text { o }\end{array}$ & హ゙ & $\begin{array}{l}\widehat{N} \\
\text { ì }\end{array}$ & 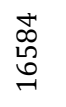 & $\stackrel{0}{\stackrel{0}{N}}$ \\
\hline$\approx \frac{\grave{d}}{\check{z}}$ & $\begin{array}{l}\infty \\
\stackrel{\infty}{\llcorner} \\
\end{array}$ & $\begin{array}{l}0 \\
\stackrel{\sim}{\sim}\end{array}$ & $\begin{array}{l}\stackrel{\infty}{m} \\
\stackrel{+}{+}\end{array}$ & $\begin{array}{l}\stackrel{8}{\circ} \\
\stackrel{\sim}{N}\end{array}$ & $\stackrel{-\infty}{\rightarrow}$ & $\stackrel{+}{\mathrm{N}}$ & $\begin{array}{l}+ \\
0 \\
0\end{array}$ & ֶ̃ & $\begin{array}{l}\text { ò } \\
\text { m } \\
\text { - }\end{array}$ & Ð & 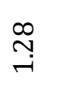 & 윰 & 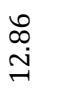 & $\underset{N}{\stackrel{N}{N}}$ & $\stackrel{\sim}{\text { ஸे }}$ \\
\hline 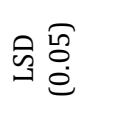 & 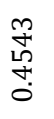 & $\begin{array}{l}0 \\
\stackrel{0}{\circ} \\
\dot{n}\end{array}$ & $\begin{array}{l}0 \\
\text { on } \\
-\end{array}$ & $\begin{array}{l}\hat{b} \\
\text { nn }\end{array}$ & $\begin{array}{l}\hat{6} \\
\infty \\
+\end{array}$ & $\stackrel{\stackrel{L}{N}}{\underset{\sim}{\sim}}$ & $\begin{array}{l}n \\
0 \\
0 \\
8 \\
0 \\
0\end{array}$ & 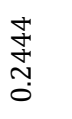 & $\begin{array}{l}\stackrel{L}{\infty} \\
\stackrel{\infty}{\infty} \\
\stackrel{m}{+}\end{array}$ & $\stackrel{+}{\stackrel{\Delta}{0}}$ & $\begin{array}{l}\text { ๙ે } \\
\text { ๙ે }\end{array}$ & $\begin{array}{l}\stackrel{\sigma}{.} \\
\stackrel{\infty}{\sigma} \\
\sim\end{array}$ & + & $\begin{array}{l}a \\
\text { ஸे } \\
\text { ஸิ }\end{array}$ & $\begin{array}{l}0 \\
\sigma \\
\sigma \\
0\end{array}$ \\
\hline
\end{tabular}

Table 1: Physicochemical Properties of the Rivers in the Area 


\begin{tabular}{|c|c|c|c|c|c|c|c|c|c|c|c|c|}
\hline Sample & $\mathrm{Cu}$ & $\mathbf{F e}$ & $\mathrm{Zn}$ & B & Mn & Co & Cd & $\mathbf{P b}$ & $\mathbf{N i}$ & $\mathrm{Cr}$ & As & $\mathrm{Hg}$ \\
\hline 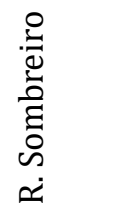 & mై & $\begin{array}{l}\stackrel{m}{\oplus} \\
\dot{0}\end{array}$ & 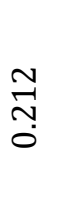 & 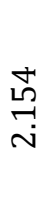 & $\begin{array}{l}\infty \\
0 \\
0 \\
0 \\
0\end{array}$ & $\begin{array}{l}\text { 己n } \\
\stackrel{0}{-}\end{array}$ & $\begin{array}{l}0 \\
0 \\
0 \\
0\end{array}$ & $\begin{array}{l}0 \\
\stackrel{7}{0}\end{array}$ & 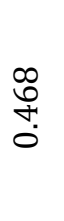 & 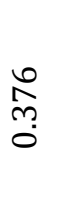 & \begin{tabular}{l}
\multirow{7}{*}{} \\
$\stackrel{0}{0}$
\end{tabular} & $\begin{array}{l}\text { Ln } \\
0 \\
0\end{array}$ \\
\hline $\begin{array}{l}\ddot{z} \\
\tilde{n} \\
\tilde{0} \\
0 \\
\sim 2\end{array}$ & $\stackrel{0}{\underset{+}{+}}$ & \begin{tabular}{l} 
Lొ \\
\multirow{+}{*}{} \\
0
\end{tabular} & 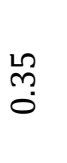 & $\begin{array}{l}\stackrel{0}{\circ} \\
\dot{m}\end{array}$ & $\stackrel{\stackrel{L}{m}}{\stackrel{0}{0}}$ & $\begin{array}{l}\stackrel{0}{N} \\
\underset{N}{\infty} \\
\stackrel{\sim}{\sim}\end{array}$ & $\begin{array}{l}\infty \\
\stackrel{0}{0} \\
0\end{array}$ & $\underset{0}{\overrightarrow{0}}$ & $\begin{array}{l}\text { ٌొ } \\
\text { Lొ? } \\
0\end{array}$ & $\begin{array}{l}\text { مे } \\
\text { m. } \\
0\end{array}$ & $\begin{array}{l}8 \\
\text { Oे } \\
0 \\
0\end{array}$ & $\begin{array}{l}\hat{A} \\
\text { Oे }\end{array}$ \\
\hline 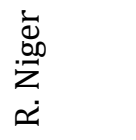 & $\begin{array}{l}\text { Lم } \\
\text { นn } \\
0\end{array}$ & $\begin{array}{l}\infty \\
\infty \\
+ \\
+ \\
0\end{array}$ & $\begin{array}{l}\infty \\
\stackrel{1}{! n} \\
0\end{array}$ & 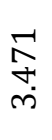 & $\stackrel{+}{\stackrel{+}{0}}$ & $\begin{array}{l}\stackrel{m}{p}+\underset{+}{\sim} \\
\text { in }\end{array}$ & $\begin{array}{l}\vec{H} \\
\dot{0} \\
0\end{array}$ & $\stackrel{l}{\circ}$ & $\begin{array}{l}\stackrel{\hat{N}}{\hat{0}} \\
\text {. }\end{array}$ & $\begin{array}{l}\text { :̊ } \\
\text { นొ } \\
0\end{array}$ & $\begin{array}{l}\infty \\
\stackrel{-}{-} \\
0\end{array}$ & $\begin{array}{l}\check{\sigma} \\
0 \\
0\end{array}$ \\
\hline 号 & $\begin{array}{l}\widetilde{O} \\
0 \\
0\end{array}$ & $\begin{array}{l}\stackrel{\vec{J}}{0} \\
0 \\
0\end{array}$ & $\begin{array}{l}0 \\
\stackrel{7}{\sim}\end{array}$ & $\begin{array}{l}\text { oे } \\
\text { in } \\
0\end{array}$ & $\begin{array}{l}\text { ָे } \\
\text { Oे } \\
\text { Oे }\end{array}$ & $\begin{array}{l}\stackrel{0}{n} \\
\text { นn } \\
0\end{array}$ & $\begin{array}{l}\vec{J} \\
\stackrel{0}{0} \\
0\end{array}$ & $\begin{array}{l}\stackrel{L}{\text { }} \\
\text { م. }\end{array}$ & $\begin{array}{l}\text { Oे } \\
\text { Oे }\end{array}$ & $\begin{array}{l}0 \\
\stackrel{0}{0} \\
0 \\
0\end{array}$ & \begin{tabular}{l}
0 \\
\multirow{2}{*}{} \\
0
\end{tabular} & $\begin{array}{l}0 \\
\text { Oे } \\
0 \\
0\end{array}$ \\
\hline
\end{tabular}

Table 2: Micronutrients and Heavy Metals Content of the Water Samples Studied 